\title{
Aliphatic Halogenated Hydrocarbons: Report and Analysis of Liver Injury in 60 Patients
}

\author{
Rolf Teschke* \\ Department of Internal Medicine II, Division of Gastroenterology and Hepatology, Klinikum Hanau, Hanau, Academic Teaching \\ Hospital of the Medical Faculty, Goethe University Frankfurt/Main, Frankfurt/Main, Germany
}

\section{Abstract}

Background and Aims: Intoxications by aliphatic halogenated hydrocarbons $(\mathrm{AHH})$, used as effective solvents, are rare and may cause life-threatening liver injury. Patients with acute intoxications by $\mathrm{AHH}$ received an innovative treatment. Methods: Analyzed were data of 60 patients intoxicated by $\mathrm{AHH}$, such as dichloromethane $(n=3)$, chloroform $(n=2)$, carbon tetrachloride $(n=12), 1,2$-dichloroethane $(n=18)$, $1,1,2$-trichloroethane $(n=2)$, trichloroethylene $(n=2)$, tetrachloroethylene $(n=13)$ or mixed $\mathrm{AHH}$ chemicals $(n=8)$, who received a new treatment consisting of $\mathrm{CO}_{2}$-induced hyperventilation to accelerate toxin removal via the lungs. Results: Added to the inspiration air at a flow rate of 2-3 Liter $\mathrm{min}^{-1}, \mathrm{CO}_{2}$ increased the respiratory volume up to 25-30 Liter $\mathrm{min}^{-1}$, ensuring forced $\mathrm{AHH}$ exhalation. This $\mathrm{CO}_{2}$-induced hyperventilation therapy was commonly well tolerated by the 60 patients and lasted for $106.0 \pm 10.5$ hours. In most cases, initially increased liver test results of aminotransferases normalized quickly under the therapy, and liver histology obtained at completion of the therapy revealed, in the majority of patients, normal findings or fatty changes, and rarely severe single cell necrosis but no confluent liver cell necrosis. Despite therapy, clinical outcome was unfavorable for $4 / 60$ patients $(6.7 \%)$ of the study cohort, due to single or combined risk factors. These included late initiation of the $\mathrm{CO}_{2}$-induced hyperventilation therapy, intentional intoxication, uptake of high amounts of $\mathrm{AHH}$, concomitant ingestion of overdosed drugs, consumption of high amounts of alcohol, and history of alcohol abuse. Conclusions: For intoxications by $\mathrm{AHH}$, effective therapy approaches including forced hyperventilation to increase toxin removal via the lungs are available and require prompt initiation.

Citation of this article: Teschke R. Aliphatic halogenated hydrocarbons: Report and analysis of liver injury in 60 patients. J Clin Transl Hepatol 2018;6(4):350-361. doi: 10.14218/JCTH.2018.00040.

Keywords: Aliphatic halogenated hydrocarbons; Dichloromethane; Chloroform; Carbon tetrachloride; 1,2-dichloroethane.

Abbreviations: $\mathrm{AHH}$, aliphatic halogenated hydrocarbons; ALA, aminolevulinic acid; ALT, alanine transaminase; $\mathrm{AST}$, aspartate transaminase; $\mathrm{CCl}_{4}$, carbon tetrachloride; CYP450, cytochrome P450; CYP450 2E1, cytochrome P450 2E1; DILI, drug-induced liver injury; GDH, glutamate dehydrogenase; ROS, reactive oxygen species.

Received: 27 June 2018; Revised: 15 August 2018; Accepted: 23 August 2018 *Correspondence to: Rolf Teschke, Department of Internal Medicine II, Klinikum Hanau, Teaching Hospital of the Goethe University of Frankfurt/Main, Leimenstrasse 20, Hanau D-63450, Germany. Tel.: +49-6181-21859, Fax: +49-61812964211, E-mail: rolf.teschke@gmx.de
Introduction

Applied in animal models, a variety of potentially hepatotoxic chemicals are known, such as ethionine, gallactosamine, nitrosamines, phosphorous and thioacetamide, and are considered as appropriate examples for experimental liver injury studies. ${ }^{1}$ However, results obtained with these substrates are rarely transferrable from animal liver injury to human liver injury cases or to general human liver diseases of alternative etiologies, such as those caused by alcohol, drugs, herbs, obesity and hepatitis B or C. Other chemicals like those of the aliphatic halogenated hydrocarbons ( $\mathrm{AHH}$ ) group with compounds presenting a broad spectrum of different structures are much more specific in producing liver injury $^{1-3}$ and have the advantage of causing liver injury in both animals ${ }^{1-13}$ and humans. ${ }^{14-16}$ Mimicking human disease, this allows for the transfer of experimental results to patients with intoxications by $\mathrm{AHH} .{ }^{14-16}$ Consequently, such data transfer helps elucidate pathogenetic steps of liver injury hits and develop new therapy strategies. ${ }^{15,16}$ This will assist clinicians caring for patients with liver injury caused by $\mathrm{AHH}$.

This article describes and analyzes the clinical experience among 60 patients with acute intoxications by seven different $\mathrm{AHH}$, including dichloromethane, chloroform, carbon tetrachloride $\left(\mathrm{CCl}_{4}\right)$, 1,2-dichloroethane, 1,1,2-trichloroethane, trichloroethylene, and tetrachloroethylene. The focus is on new therapy approaches based on results of experimental and clinical studies, which include increased pulmonary removal of the toxin via the innovative $\mathrm{CO}_{2}$-induced hyperventilation therapy and decreased production of toxic intermediates generated from the parent chemical.

\section{Methods}

\section{Patients}

The study cohort consisted of 60 patients with acute intoxications by seven different $\mathrm{AHH}$, who were treated at the Intensive Care Unit affiliated to the Medical Departments of the Heinrich Heine University Hospital in Düsseldorf, Germany. The diagnosis of $\mathrm{AHH}$ intoxication was verified in the expiration air by the Draeger-tube ${ }^{\circledR}$ system ${ }^{15,16}$ or in the blood by head space gas liquid chromatography, ${ }^{8,9,14}$ whereby venous blood was taken with a gas-tight syringe from the cubital vein of the patient. ${ }^{14}$ In the Intensive Care Unit, electrocardiogram was performed at admission and during the clinical course; also, regularly, all essential cardiorespiratory parameters, diagnostic techniques, and laboratory tests were performed. 
All patients received the therapy as systematically described in earlier reports. ${ }^{15,16}$

\section{Treatment modalities}

Patients intoxicated by $\mathrm{AHH}$ through ingestion or inhalation were treated as outlined in detail in Table 1.

\section{Hyperventilation for increasing АHH elimination via lungs}

To get the body rid of the toxin, an increased pulmonary removal is recommended, best achieved by artificial hyperventilation through $\mathrm{CO}_{2}$ at a flow rate of 2-3 Liter $\mathrm{min}^{-1}$ applied via a conventional nose tube or a conventional sealed nasal oxygen mask, with general details and potentially improved mask devices published recently. ${ }^{15,16}$ This is certainly the preferred and most innovative approach in adult and adolescent patients with sustained spontaneous respiration. However, in patients with insufficient spontaneous breathing and especially in children, who are quickly exhausted if treated with the nasal tube or the mask device, endotracheal intubation is recommended, whereby $\mathrm{CO}_{2}$ at a flow rate of $2-3$ Liter $\mathrm{min}^{-1}$ is added to the inspiration air. ${ }^{15,16}$ Independent from the mode of $\mathrm{CO}_{2}$ treatment, a respiratory volume of 25-30 Liter $\mathrm{min}^{-1}$ should be achieved, to be verified by regular measurement of the minute respiratory volume in order to achieve early recognition of problems requiring technical adjustments of the $\mathrm{CO}_{2}$ flow or eventually stopping the therapy.

Table 1. Therapy of patients with acute intoxications by AHH

\begin{tabular}{|c|c|c|}
\hline Therapy approaches & Ingestion & Inhalation \\
\hline $\begin{array}{l}\text { 1. Qualitative and quantitative } \\
\text { analysis of } \mathrm{AHH} \text { as the } \\
\text { suspected toxin, associated with } \\
\text { evaluation of individual toxicity } \\
\text { risk }\end{array}$ & + & + \\
\hline $\begin{array}{l}\text { 2. Endotracheal intubation after } \\
\text { evaluation for individual risk of } \\
\text { aspiration due to } \mathrm{AHH} \text { ingestion }\end{array}$ & + & - \\
\hline $\begin{array}{l}\text { 3. Primary toxin elimination by } \\
\text { gastro-intestinal lavage in the } \\
\text { intubated patient }\end{array}$ & + & - \\
\hline $\begin{array}{l}\text { 4. Forced } \mathrm{CO}_{2} \text {-induced } \\
\text { ventilation }\end{array}$ & + & + \\
\hline 5. Central venous access & + & + \\
\hline $\begin{array}{l}\text { 6. Intravenous cimetidine as } \\
\text { bolus ( } 200 \mathrm{mg} \text { ), then } 1600 \mathrm{mg} \\
\text { for the initial } 24 \text { hours via } \\
\text { infusion pump and for the } \\
\text { subsequent days }\end{array}$ & + & + \\
\hline $\begin{array}{l}\text { 7. Intravenous } 400 \mathrm{~g} \text { glucose/ } \\
24 \text { hours at admission and on } \\
\text { subsequent days }\end{array}$ & + & + \\
\hline $\begin{array}{l}\text { 8. Intravenous electrolytes and } \\
\text { forced diuresis }\end{array}$ & + & + \\
\hline $\begin{array}{l}\text { 9. Liquemin } 15,000 \mathrm{IU} / 24 \text { hours } \\
\text { at admission and on subsequent } \\
\text { days }\end{array}$ & + & + \\
\hline
\end{tabular}

Chronic obstructive pulmonary disease is commonly a contraindication for a $\mathrm{CO}_{2}$-induced therapy or requires a case by case decision whether a cautious therapy can be initiated under strict surveillance. All patients with acute $\mathrm{AHH}$ intoxication requiring therapy should be treated in a special setting, such as an intensive care unit that provides experienced pulmonologists and gastroenterologists, as this is a critical therapy in need of a careful 24-hour surveillance of the patient with a regular medical and technical control management.

\section{Cimetidine for inhibiting microsomal AHH metabolism}

Liver injury of $\mathrm{AHH}$, including $\mathrm{CCl}_{4}$, depends on its microsomal conversion to toxic intermediates through cytochrome P450 (CYP), especially its isoenzyme CYP 2E1.3,16 Reducing the microsomal metabolism of AHH can be another therapy strategy, using chemicals or drugs that compete with $\mathrm{AHH}$ at the site of CYP. For instance, such a competing drug is cimetidine, which reduced liver injury and lethality rate in the $\mathrm{CCl}_{4}$ animal model. ${ }^{13}$ Based on these experimental results, cimetidine has been introduced early as an essential part in the therapy management of humans intoxicated by $\mathrm{AHH}$ (Table 1). ${ }^{15,16}$ Cimetidine may also be protective in kidneys which exhibit CYP450 $2 \mathrm{E} 1,{ }^{16,17}$ possibly responsible for renal injury associated with liver injury found in some patients intoxicated by $\mathrm{AHH} .{ }^{15,16,18}$

\section{Glucose for down-regulating microsomal functions}

High-dose glucose, daily $400 \mathrm{~g}$ for a few days, is advised as part of the infusion program in patients intoxicated by $\mathrm{AHH}$ (Table 1$),{ }^{15,16}$ in analogy to the high amounts of glucose given to patients with acute intermittent porphyria. ${ }^{19}$ This allows down-regulation of the hepatic $\delta$-aminolevulinic acid (ALA) synthase activity, helping to reduce ALA synthesis, 20,21 and impairs the synthesis of heme that is essential for the hemoprotein CYP. ${ }^{21}$ This ALA-dependent pathway has been established by studies through incorporation of radioactive ALA into microsomal CYP. ${ }^{22}$

\section{Results}

\section{Intoxicating АHH chemicals and affected patients}

The overall study cohort consisted of 60 patients, with 52 patients intoxicated by single $\mathrm{AHH}$ and 8 patients with intoxication by $\mathrm{AHH}$ chemical mixtures classified as mixed $\mathrm{AHH}$ chemical intoxications. The 52 patients had been intoxicated by seven single $\mathrm{AHH}$, with preference of 1,2-dichloroethane intoxicating 18 patients, trichloroethylene affecting 13 patients, and $\mathrm{CCl}_{4}$ injuring 12 patients (Supplemental Table 1 ). The remaining $\mathrm{AHH}$ injured $2-3$ patients.

\section{Demographic data of the cohort and mode of intoxication}

The 60 patients were $41.3 \pm 3.9$ years-old, with a first peak occurring between 15 and 24 years of age and a second peak between 35 and 54 years of age (Fig. 1A). Patients with an accidental intoxication were significantly older compared to those with an intentional intoxication ( $49.8 \pm 6.5$ vs. $31.6 \pm 2.8$ years; $p<0.005)$. Age was also variable among the different subgroups of intoxicating $\mathrm{AHH}$ chemicals (Supplemental Table 1). 
Intoxications by $\mathrm{AHH}$ occurred mostly by ingestion and rarely by inhalation. There were slightly more intoxications with an unintentional than an intentional background, and male patients constituted the majority among the study cohort (Fig. 1B). More specifically, in the cohort, the ratio of males:females was $2.5: 1$, based on 43 male patients and 17 female patients. Gender differences are also evident for the criteria of ingestion, inhalation, intentional use, and unintentional uptake (Fig. 1C). During the day, a high peak of intoxication was at 4:00 p.m., and another but lower peak occurred at 11:00 a.m. (Fig. 1D). For the week days, most of the intoxications occurred on Tuesday, followed by Friday
Teschke R.: Aliphatic halogenated hydrocarbons and liver

and Saturday (Fig. 1E). For time of year, intoxications by $\mathrm{AHH}$ occurred most frequently in January, followed by June (Fig. 1F).

\section{Hyperventilation details}

Duration of the hyperventilation therapy was $106.0 \pm 10.5$ hours among the 60 patients. Data were variable among the single chemical intoxicants and the mixed chemical intoxication subgroup and were also stratified according to whether the intoxication had an intentional or an
A

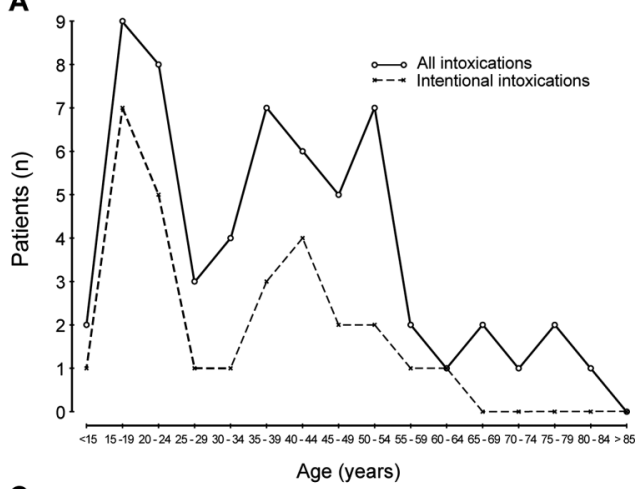

B

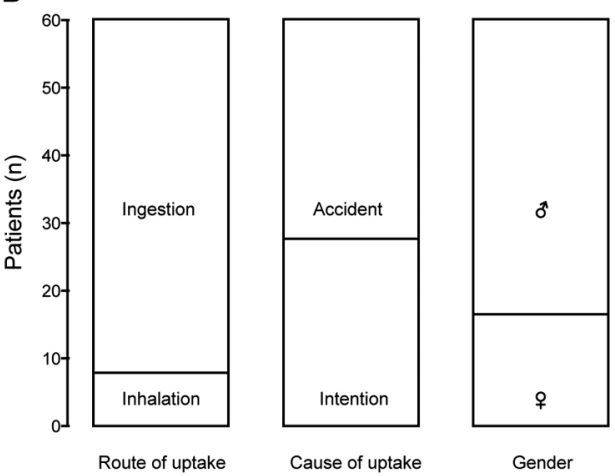

C

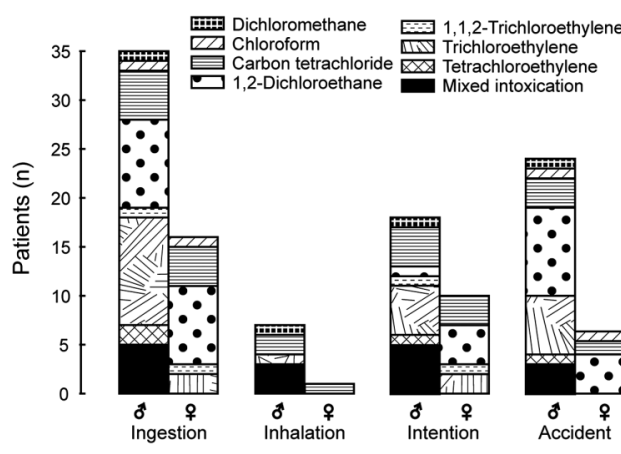

$\mathbf{E}$

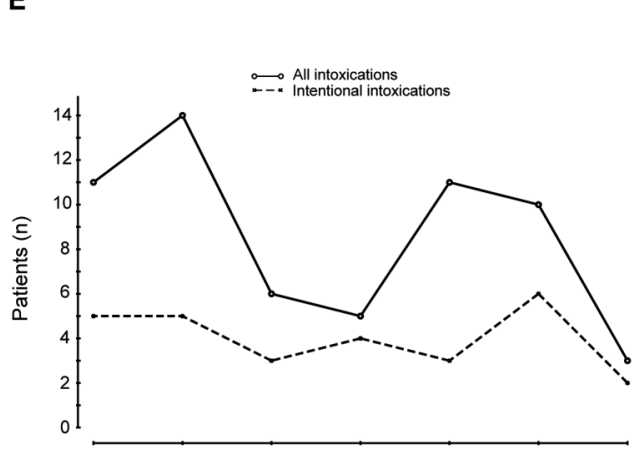

Monday Tuesday Wednesday Thursday Friday Saturday Sunday
D

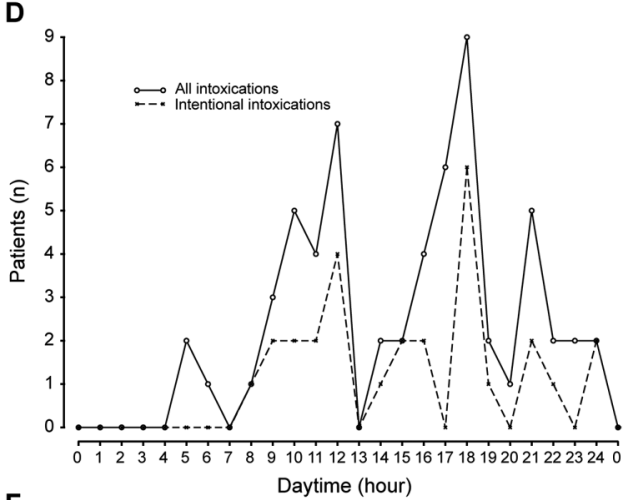

$\mathbf{F}$

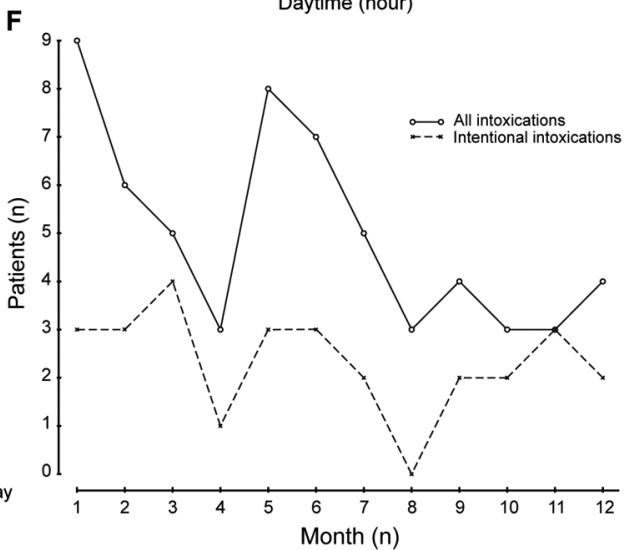

Fig. 1. (A) Age distribution of the 60 patients with intoxication by AHH. (B) Route of AHH uptake, cause of intoxication, and sex distribution among the 60 patients of the study cohort. (C) Sex distribution in relation of the criteria ingestion, inhalation, and background of intoxication among the 60 patients included in the study cohort. (D) Day time of AHH intoxication among the 60 patients of the study cohort. (E) Weekday of intoxication among the study cohort comprising 60 patients with AHH intoxication. (F) Month of intoxication in the study cohort of 60 patients.

Abbreviation: $\mathrm{AHH}$, aliphatic halogenated hydrocarbons. 


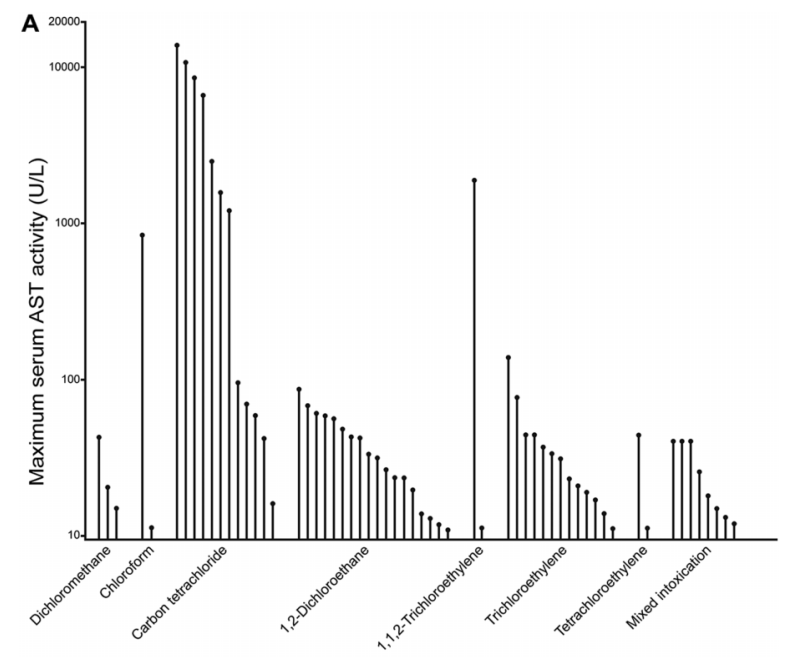

unintentional background (Supplemental Table 2). Discharge was after $14.5 \pm 1.5$ days, calculated from the day of intoxication.

\section{Liver injury}

Upon assessing maximum serum activities of alanine transaminase (AST) and alanine transaminase (ALT) in the study cohort of 60 patients during the hyperventilation treatment, variable results were evident among the $\mathrm{AHH}$ (Fig. $2 \mathrm{~A}$ and 2B). In patients intoxicated by $\mathrm{CCl}_{4}$, extremely high values were found for AST (Fig. 2A) and ALT (Fig. 2B).

In the initial phase of the clinical study, patients underwent liver biopsy or laparoscopy to obtain liver specimens. Among the 17 patients studied for liver changes, the liver of 12 patients appeared normal upon staining by hematoxylin \& eosin or showed steatosis (Supplemental Table 3). However, 2 of the remaining patients tolerated only short-term hyperventilation therapy and their liver disease had to be classified as severe hepatocellular, whereas in 3 other patients, severe liver cell necrosis was found, triggered likely by preexisting alcohol abuse or caused by ingestion of high amounts of $\mathrm{AHH}$. More importantly, among patients with normal or near normal liver histology by light microscopy, electron microscopy data were available for a few patients, showing hepatocellular changes such as mitochondrial injury. As expected, liver injurious effects, though at a low level, were still evident at the time of discontinuation of the therapeutic hyperventilation, but this is not of clinical relevance and does not require a prolongation of the hyperventilation therapy. In the further course after discharge, complete restoration of the previous liver injury is expected but it may take some time, until the $\mathrm{AHH}$ stored in various organs, including the fat tissue, has left the body. Considering these aspects, all patients were advised at discharge to abstain from alcohol use for at least 3 months.

\section{Renal injury}

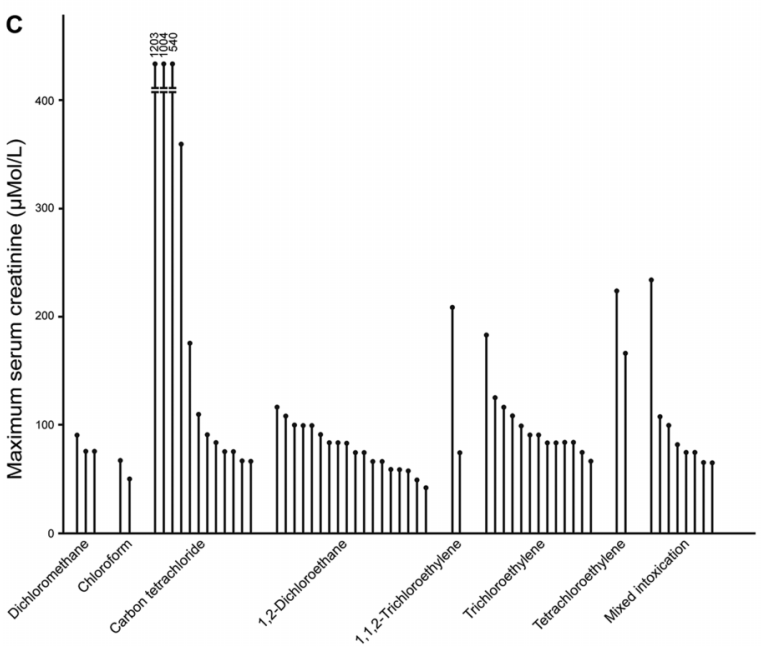

Maximum serum creatinine values are illustrated for all AAH during the hyperventilation therapy, with the highest values found in patients intoxicated by $\mathrm{CCl}_{4}$ (Fig. 2C). Therefore, all patients intoxicated by $\mathrm{AHH}$ require continuous analysis of serum creatinine values and early decision to introduce forced diuresis (Table 1 ), to help prevent or ameliorate renal insufficiency. Despite these preventive measures, a few patients of the study cohort required dialysis.

\section{Clinical course and outcome}

A brief overview of the 52 patients with intoxications by a single $\mathrm{AHH}$ is presented in Table 2 and of the 8 patients with mixed chemical intoxications by $\mathrm{AHH}$ in Table 3 .

Clinical course was favorable among $56 / 60$ patients, but outcome was fatal in $4 / 60$ patients, corresponding to a lethality rate of $6.7 \%$. In those patients with a fatal outcome, the ratio of males:females was 3:1. All patients with a fatal outcome had used $\mathrm{AHH}$ intentionally (cases 13, 37 and 47 in Table 2; case 7 in Table 3). In more detail, a 22 year-old male patient (case 7 in Table 3 ) ingested $60 \mathrm{~mL}$ 1,2-dichloroethane plus $90 \mathrm{mL1}, 1,2$-trichloroethane and was treated by $\mathrm{CO}_{2}$-induced hyperventilation, initiated 5 hours after intoxication; death occurred 25 hours after the intoxication (case 7 in Table 3). The second patient (case 37 
Teschke R.: Aliphatic halogenated hydrocarbons and liver

Table 2. Selected case details of 52 patients with acute single chemical intoxication by seven aliphatic halogenated hydrocarbons treated with the $\mathrm{CO}_{2}-$ induced hyperventilation

\begin{tabular}{|c|c|c|}
\hline Case & $\begin{array}{l}\text { AHH intoxication; } \\
\text { Route (amount) }\end{array}$ & Selected case details of 52 patients under $\mathrm{CO}_{2}$-induced hyperventilation \\
\hline $\begin{array}{l}\text { 1. Male, } \\
46 \text { years }\end{array}$ & $\begin{array}{l}\text { Dichloromethane; } \\
\text { Ingestion ( } 45 \mathrm{~mL} \text { ) }\end{array}$ & $\begin{array}{l}\text { Intentional ingestion with subsequent vomiting. Awake at admission. Clinically } \\
\text { lacking signs of toxicity with good outcome. }\end{array}$ \\
\hline $\begin{array}{l}\text { 2. Male, } \\
49 \text { years }\end{array}$ & $\begin{array}{l}\text { Dichloromethane; } \\
\text { Inhalation }(20 \mathrm{~mL})\end{array}$ & Accidental inhalation. No narcosis. No apparent clinical toxicity. \\
\hline $\begin{array}{l}\text { 3. Female, } \\
50 \text { years }\end{array}$ & $\begin{array}{l}\text { Dichloromethane; } \\
\text { Ingestion }(40 \mathrm{~mL})\end{array}$ & $\begin{array}{l}\text { Unintentional ingestion with subsequent self-induced vomiting. Dizziness. } \\
\text { Subsequent uneventful clinical course. }\end{array}$ \\
\hline $\begin{array}{l}\text { 4. Male, } \\
21 \text { years }\end{array}$ & $\begin{array}{l}\text { Chloroform; } \\
\text { Ingestion ( } 50 \mathrm{~mL})\end{array}$ & $\begin{array}{l}\text { Following consumption of beer }(1.5 \mathrm{~L}) \text {, unintentional ingestion of chloroform. } \\
\text { Seizures. Narcosis requiring endotracheal intubation for gastrointestinal lavage and } \\
\text { short-term artificial ventilation. }\end{array}$ \\
\hline $\begin{array}{l}\text { 5. Female, } \\
51 \text { years }\end{array}$ & $\begin{array}{l}\text { Chloroform; } \\
\text { Ingestion }(10 \mathrm{~mL})\end{array}$ & Unintentional ingestion of chloroform. Lack of clinical toxicity. \\
\hline $\begin{array}{l}\text { 6. Male, } \\
15 \text { years }\end{array}$ & $\mathrm{CCl}_{4} ;$ Ingestion $(30 \mathrm{~mL})$ & $\begin{array}{l}\text { Patient swallowed } \mathrm{CCl}_{4} \text { intentionally and experienced vomiting twice. On day } 3 \text { after } \\
\text { intoxication, serum activities of liver enzymes slightly increased, reached a } \\
\text { maximum on day } 4 \text {, and normalized until day } 14 \text { after intoxication. Liver biopsy on } \\
\text { day } 13 \text { showed no abnormalities. }\end{array}$ \\
\hline $\begin{array}{l}\text { 7. Female, } \\
14 \text { years }\end{array}$ & $\begin{array}{l}\mathrm{CCl}_{4} ; \text { Ingestion } \\
(10-20 \mathrm{~mL})\end{array}$ & $\begin{array}{l}\text { Intentional ingestion of } \mathrm{CCl}_{4} \text { accessed from a dry cleaning business where her mother } \\
\text { was employed. She was fully oriented. Liver histology at termination of the } \\
\text { hyperventilation therapy showed no overt liver cell necrosis but severe microvesicular } \\
\text { fatty liver in } 80-90 \% \text { of the liver cells. By electron microscopy, cristae of mitochondria } \\
\text { were reduced and disorganized. Within the mitochondria, crystalline inclusion bodies } \\
\text { were found. At discharge all laboratory values were in the normal range. }\end{array}$ \\
\hline $\begin{array}{l}\text { 8. Male, } \\
31 \text { years }\end{array}$ & $\mathrm{CCl}_{4} ;$ Ingestion $(50 \mathrm{~mL})$ & $\begin{array}{l}\text { Patient intentionally swallowed } \mathrm{CCl}_{4} \text { and was found by his mother. After initial } \\
\text { treatment in a local hospital and recurrent vomiting, his clinical course was } \\
\text { uneventful, except for a short increase of serum AST and ALT activities during days } 3 \\
\text { and } 5 \text { after ingestion. }\end{array}$ \\
\hline $\begin{array}{l}\text { 9. Male, } \\
70 \text { years }\end{array}$ & $\begin{array}{l}\mathrm{CCl}_{4} ; \text { Ingestion } \\
(\sim 50 \mathrm{~mL})\end{array}$ & $\begin{array}{l}\text { Patient unintentionally ingested } \mathrm{CCl}_{4} \text { contained in a bottle labeled erroneously as } \\
\text { lemonade. He was sleepy and experienced diarrhea with black-colored stools, with } \\
\text { later recurrent vomiting also. Peak serum activities for AST and ALT were observed } \\
\text { on day } 7 \text { after ingestion. }\end{array}$ \\
\hline $\begin{array}{l}\text { 10. Male, } \\
40 \text { years }\end{array}$ & $\begin{array}{l}\mathrm{CCl}_{4} ; \text { Ingestion } \\
(100 \mathrm{~mL})\end{array}$ & $\begin{array}{l}\text { Following intentional ingestion of } \mathrm{CCl}_{4} \text {, the somnolent patient received short-term } \\
\text { endotracheal intubation for initiating } \mathrm{CO}_{2} \text {-induced hyperventilation during transport } \\
\text { via plane. Maximum values for serum activities of ASTand ALT were observed on day } \\
4 \text { after ingestion, associated with an increase of serum creatinine. Liver histology on } \\
\text { day } 14 \text { after ingestion revealed moderate centrilobular microvesicular fatty liver } \\
\text { with low liver cell necrosis. Electron microscopy showed a striking proliferation and } \\
\text { pronounced dilatation of the smooth endoplasmic reticulum of the hepatocytes. } \\
\text { These dilated cisterns contained small membrane vortexes, similar to myelin. In the } \\
\text { cytoplasm, vacuoles predominated. Mitochondria were enlarged and showed } \\
\text { degeneration and vacuoles. Microvilli presented with injurious irregularities. } \\
\text { Abnormal laboratory results returned to normal values rapidly. }\end{array}$ \\
\hline $\begin{array}{l}\text { 11. Female, } \\
50 \text { years }\end{array}$ & $\begin{array}{l}\mathrm{CCl}_{4} ; \text { Inhalation } \\
(\sim 10 \mathrm{~mL})\end{array}$ & $\begin{array}{l}\text { Unintentional intoxication was by inhalation of } \mathrm{CCl}_{4} \text {, which the patient used for } \\
\text { cleaning of a spot on her carpet. She experienced nausea for a day and had a blood } \\
\text { ethanol level of } 1.77 \text {. Under hyperventilation therapy, serum activities of AST and } \\
\text { ALT remained virtually unchanged. }\end{array}$ \\
\hline $\begin{array}{l}\text { 12. Female, } \\
50 \text { years }\end{array}$ & $\begin{array}{l}\mathrm{CCl}_{4} ; \text { Ingestion } \\
(\sim 50 \mathrm{~mL})\end{array}$ & $\begin{array}{l}\text { Patient unintentionally swallowed } \mathrm{CCl}_{4} \text { contained in a mineral water bottle and } \\
\text { vomited intentionally. Symptoms included severe headaches and nausea. Peak } \\
\text { enzyme activities were determined for serum AST and ALT } 4 \text { days after ingestion, } \\
\text { with retarded decline and normalization. }\end{array}$ \\
\hline $\begin{array}{l}\text { 13. Male, } \\
36 \text { years }\end{array}$ & $\mathrm{CCl}_{4} ;$ Ingestion $(50 \mathrm{~mL})$ & $\begin{array}{l}\left.\text { Patient intentionally ingested } \mathrm{CCl}_{4} \text { and consumed beer ( } \sim 2.5 \text { Liter }\right) \text { and hard liquor } \\
(\sim 0.5 \text { Liter). At admission, his blood ethanol was } 2.5-3.0 \text {. On day } 3 \text { after ingestion, } \\
\text { a peak activity was observed for AST and AST, with subsequent decline. Serum total } \\
\text { bilirubin and creatinine increased steadily. Endotracheal intubation, dialysis, and } \\
\text { two reanimations were required. Complications included acute liver failure, } \\
\text { pneumonia, and respiratory insufficiency, leading to a fatal outcome. }\end{array}$ \\
\hline
\end{tabular}

(continued) 
Teschke R.: Aliphatic halogenated hydrocarbons and liver

Table 2. (continued)

$\begin{array}{ll} & \text { AHH intoxication; } \\ \text { Case } & \text { Route (amount) }\end{array}$

14. Female, $\mathrm{CCl}_{4}$; Inhalation

22 years $\quad(\sim 50 \mathrm{~mL})$

15. Male, $\quad \mathrm{CCl}_{4}$; Inhalation

33 years (amount?)

\begin{abstract}
16. Female, $\mathrm{CCl}_{4}$; Inhalation
29 years (amount?)
\end{abstract}

17. Male,

31 years
$\mathrm{CCl}_{4}$; Inhalation

(amount?)

\begin{tabular}{|c|c|}
\hline $\begin{array}{l}\text { 18. Male, } \\
37 \text { years }\end{array}$ & $\begin{array}{l}\text { 1,2-Dichloroethane; } \\
\text { Ingestion (15 mL) }\end{array}$ \\
\hline $\begin{array}{l}\text { 19. Male, } \\
40 \text { years }\end{array}$ & $\begin{array}{l}\text { 1,2-Dichloroethane; } \\
\text { Ingestion }(15-20 \mathrm{~mL}\end{array}$ \\
\hline $\begin{array}{l}20 . \text { Male, } \\
16 \text { years }\end{array}$ & $\begin{array}{l}\text { 1,2-Dichloroethane; } \\
\text { Ingestion }(\sim 50 \mathrm{~mL})\end{array}$ \\
\hline $\begin{array}{l}21 . \text { Female, } \\
24 \text { years }\end{array}$ & $\begin{array}{l}\text { 1,2-Dichloroethane; } \\
\text { Ingestion }(7 \mathrm{~mL})\end{array}$ \\
\hline $\begin{array}{l}\text { 22. Male, } \\
48 \text { years }\end{array}$ & $\begin{array}{l}\text { 1,2-Dichloroethane; } \\
\text { Ingestion }(5 \mathrm{~mL})\end{array}$ \\
\hline $\begin{array}{l}\text { 23. Male, } \\
44 \text { years }\end{array}$ & $\begin{array}{l}\text { 1,2-Dichloroethane; } \\
\text { Ingestion ( } 25 \mathrm{~mL})\end{array}$ \\
\hline $\begin{array}{l}\text { 24. Female, } \\
17 \text { years }\end{array}$ & $\begin{array}{l}\text { 1,2-Dichloroethane; } \\
\text { Ingestion }(40 \mathrm{~mL})\end{array}$ \\
\hline $\begin{array}{l}25 . \text { Male, } \\
46 \text { years }\end{array}$ & $\begin{array}{l}\text { 1,2-Dichloroethane; } \\
\text { Ingestion }(5 \mathrm{~mL})\end{array}$ \\
\hline
\end{tabular}

Selected case details of 52 patients under $\mathrm{CO}_{2}$-induced hyperventilation

Intentional inhalation of $\mathrm{CCl}_{4}$ led to nausea, stomach cramps, tachycardia, and intermittent somnolence. Prompted decline of initially increased serum activities of ALT and AST.

As a conservator and owner of a business for restoring oil paintings and art work, the patient unintentionally inhaled $\mathrm{CCl}_{4}$ for several days, a typical occupational intoxication. Symptoms included loss of appetite, nausea, vomiting, headaches and pains in the neck. Throughout the clinical course, values of serum total bilirubin and creatinine remained in the normal range. Previous alcohol use of 0.7 Liter wine and 0.2 Liter beer daily was considered as risk factor of the liver toxicity by $\mathrm{CCl}_{4}$. On day 5 after admission, liver histology showed a moderate steatosis with small and large fat droplets as well as some inflammation but no necrosis. By electron microscopy, the mitochondria were swollen and their cristae were reduced. Abundant bile pigments were seen between the nucleus and bile canaliculus. Initially increased serum activities for AST and ALT normalized rapidly.

Patient unintentionally inhaled $\mathrm{CCl}_{4}$ for $4-5$ weeks under similar working conditions as described for Patient 15 above, in whose business she was employed as conservator. Symptoms included malaise, loss of appetite, fever, dark urine, flu-like joint pains and back pains. Her alcohol use was quantified as 2 Liter wine per week. Liver histology obtained 3 days after cessation of the hyperventilation therapy showed in zone 3 a mild steatosis involving $20-30 \%$ of the hepatocytes, severe single cell necrosis, and a moderate activation of hepatic stellate cells. The clinical course was complicated by oliguric renal insufficiency, treated with forced diuresis. The initially increased serum activities of AST and ALT normalized until day 11.

Patient unintentionally inhaled $\mathrm{CCl}_{4}$ and had worked together with Patients 15 and 16 above in the business of Patient 15 above and under similar working conditions. Symptoms included nausea, headaches, joint pains, lower back pains, sore throat, dark urine, vomiting and diarrhea. Via a university hospital, he was transferred by helicopter, together with Patient 11, to our Intensive Care Unit. He showed beginning withdrawal symptoms, likely related to his alcohol use which was reported as 2.5 Liter beer daily and occasionally more. Initially increased serum activities of AST and ALT normalized within 17 days. Liver histology obtained 39 days after the last $\mathrm{CCl}_{4}$ exposure showed a low-grade fatty liver and residues of a toxic event. Complications included basal pneumonia, respiratory insufficiency requiring $\mathrm{O}_{2}$ application, and renal insufficiency requiring intermittent hemodialysis on 12 days. Discharge was possible after 42 days in fairly good condition. This case, as well as the 2 cases above, had been reported to the respective trade association. Accidental ingestion, vomiting. During weekends, $1.0-1.5$ Liter beer. Marginally increased serum activities of AST and ALT.

Unintentional uptake. No symptoms at admission. Minimally increased serum activities of AST and ALT.

Intentional ingestion. Gastrointestinal lavage in the local hospital. Serum activities of AST and ALT remained in the normal range.

Accidental ingestion. Normal serum AST and ALT.

Unintentional ingestion. Vomiting, subsequent nausea. Serum activities of AST and ALT were slightly increased.

Accidental uptake, self-induced vomiting followed by spontaneous vomiting, nausea. Superficial ulceration of the tongue. Slightly increased serum values of AST and ALT.

Intentional ingestion, with $100 \mathrm{mg}$ medazepam and $1.0 \mathrm{~L}$ beer. Recurrent vomiting. Transfer by helicopter. Small increases of serum AST and ALT activities.

Accidental ingestion, vomiting. Uneventful clinical course with normal serum activities of AST and ALT. 
Teschke R.: Aliphatic halogenated hydrocarbons and liver

Table 2. (continued)

\begin{tabular}{|c|c|c|}
\hline Case & $\begin{array}{l}\text { AHH intoxication; } \\
\text { Route (amount) }\end{array}$ & Selected case details of 52 patients under $\mathrm{CO}_{2}$-induced hyperventilation \\
\hline $\begin{array}{l}\text { 26. Male, } \\
78 \text { years }\end{array}$ & $\begin{array}{l}\text { 1,2-Dichloroethane; } \\
\text { Ingestion ( } 35 \mathrm{~mL})\end{array}$ & $\begin{array}{l}\text { Unintentional ingestion after alcohol use. Vomiting and nausea. Cautious } \mathrm{CO}_{2}- \\
\text { induced hyperventilation for } 5 \text { days, premature cessation due to COPD. Slight } \\
\text { increases of AST and ALT activities. }\end{array}$ \\
\hline $\begin{array}{l}\text { 27. Male, } \\
37 \text { years }\end{array}$ & $\begin{array}{l}\text { 1,2-Dichloroethane; } \\
\text { Ingestion ( } 35 \mathrm{~mL})\end{array}$ & $\begin{array}{l}\text { Unintentional ingestion, vomiting. Gastrointestinal lavage. Virtually normal serum } \\
\text { AST and ALT activities. }\end{array}$ \\
\hline $\begin{array}{l}\text { 28. Male, } \\
34 \text { years }\end{array}$ & $\begin{array}{l}\text { 1,2-Dichloroethane; } \\
\text { Ingestion }(15 \mathrm{~mL})\end{array}$ & $\begin{array}{l}\text { Accidental ingestion. Gastrointestinal lavage in local hospital. Slightly increased } \\
\text { serum activities of AST and ALT. }\end{array}$ \\
\hline $\begin{array}{l}\text { 29. Male, } \\
35 \text { years }\end{array}$ & $\begin{array}{l}\text { 1,2-Dichloroethane; } \\
\text { Ingestion }(25 \mathrm{~mL})\end{array}$ & $\begin{array}{l}\text { Unintentional ingestion, vomiting several times. Transfer by helicopter. Dizziness } \\
\text { and nausea. Slightly increased serum activities of AST and ALT. }\end{array}$ \\
\hline $\begin{array}{l}\text { 30. Female, } \\
18 \text { years }\end{array}$ & $\begin{array}{l}\text { 1,2-Dichloroethane; } \\
\text { Ingestion }(80 \mathrm{~mL})\end{array}$ & $\begin{array}{l}\text { Intentional ingestion, vomiting at home. Minimally increased serum activities of AST } \\
\text { and ALT. }\end{array}$ \\
\hline $\begin{array}{l}\text { 31. Female, } \\
57 \text { years }\end{array}$ & $\begin{array}{l}\text { 1,2-Dichloroethane; } \\
\text { Ingestion }(50 \mathrm{~mL})\end{array}$ & $\begin{array}{l}\text { Intentional ingestion, then vomiting, and gastrointestinal lavage. Moderate alcohol } \\
\text { use. Under hyperventilation therapy, normal AST and ALT. }\end{array}$ \\
\hline $\begin{array}{l}\text { 32. Female, } \\
79 \text { years }\end{array}$ & $\begin{array}{l}\text { 1,2-Dichloroethane; } \\
\text { Inhalation }(\sim 8 \mathrm{~mL})\end{array}$ & $\begin{array}{l}\text { Unintentional inhalation with usual treatment thereafter. Marginally increased } \\
\text { serum activities of AST and ALT. }\end{array}$ \\
\hline $\begin{array}{l}\text { 33. Male, } \\
32 \text { years }\end{array}$ & $\begin{array}{l}\text { 1,2-Dichlorethane; } \\
\text { Inhalation }(\sim 6 \mathrm{~mL})\end{array}$ & $\begin{array}{l}\text { Unintentional inhalation for } 2 \text { hours. Vomiting and nausea. Minimally increased } \\
\text { serum activities of AST and ALT. }\end{array}$ \\
\hline $\begin{array}{l}\text { 34. Female, } \\
81 \text { years }\end{array}$ & $\begin{array}{l}\text { 1,2-Dichloroethane } \\
\text { Ingestion }(20 \mathrm{~mL})\end{array}$ & $\begin{array}{l}\text { Unintentional ingestion, immediate vomiting and later short somnolence. } \\
\text { Gastrointestinal lavage. Single defibrillation for cardiac ventricular flutter. Under } \\
\text { therapy, virtually normal serum activities of AST and ALT. }\end{array}$ \\
\hline $\begin{array}{l}35 . \text { Female, } \\
21 \text { year }\end{array}$ & $\begin{array}{l}\text { 1,2-Dichloroethane; } \\
\text { Ingestion ( } 35 \mathrm{~mL})\end{array}$ & $\begin{array}{l}\text { Intentional intake, with prior ingestion of } 20 \mathrm{~mL} \text { hard liquor. Vomiting. } \\
\text { Gastrointestinal lavage. Serum activities of AST and ALT remained normal. }\end{array}$ \\
\hline $\begin{array}{l}\text { 36. Female, } \\
20 \text { years }\end{array}$ & $\begin{array}{l}\text { 1,1,2-Trichloroethane; } \\
\text { Ingestion }(100 \mathrm{~mL})\end{array}$ & $\begin{array}{l}\text { Intentional ingestion, together with oxaxepam ( } 20 \text { tablets). Narcosis. Systemic } \\
\text { seizures. Vomiting and nausea. ECG: significant extrasystoles. Acrocyanosis. Rapid } \\
\text { start of } \mathrm{CO}_{2} \text {-induced hyperventilation. Serum activities of AST and ALT remained } \\
\text { normal. }\end{array}$ \\
\hline $\begin{array}{l}\text { 37. Male, } \\
19 \text { years }\end{array}$ & $\begin{array}{l}\text { 1,1,2-Trichloroethane; } \\
\text { Ingestion (unknown } \\
\text { amount) }\end{array}$ & $\begin{array}{l}\text { Intentional ingestion, also of temazepam ( } 340 \mathrm{mg} \text { ). Found unconscious. For } 4 \text { days, } \\
\text { initial treatment in a local hospital, gastrointestinal lavage. At transfer, intubated, } \\
\text { moribund, and death the other day. Forced diuresis. Artificial ventilation. Before } \\
\text { death, maximum serum activities: AST } 1870 \mathrm{U} / \mathrm{L} \text {, ALT } 2950 \mathrm{U} / \mathrm{L} \text {. }\end{array}$ \\
\hline $\begin{array}{l}\text { 38. Male, } \\
49 \text { years }\end{array}$ & $\begin{array}{l}\text { Trichloroethylene; } \\
\text { Ingestion }(40 \mathrm{~mL})\end{array}$ & $\begin{array}{l}\text { Unintentional ingestion. Vomiting, diarrhea. Dizziness. Transfer by airplane and } \\
\text { start, on board, with } \mathrm{CO}_{2} \text {-induced hyperventilation, which was continued for } 4 \text { days } \\
\text { and caused undetectable blood levels of the AHH and virtually normal serum } \\
\text { activities of AST and ALT. }\end{array}$ \\
\hline $\begin{array}{l}\text { 39. Male, } \\
50 \text { years }\end{array}$ & $\begin{array}{l}\text { Trichloroethylene; } \\
\text { Ingestion }(100 \mathrm{~mL})\end{array}$ & $\begin{array}{l}\text { Unintentional ingestion. Narcosis. Transport by airplane, narcosis receded. Incipient } \\
\text { pneumonia. Serum activities of AST and ALT remained in the normal range. }\end{array}$ \\
\hline $\begin{array}{l}\text { 40. Male, } \\
55 \text { years }\end{array}$ & $\begin{array}{l}\text { Trichloroethylene; } \\
\text { Ingestion ( } 50 \mathrm{~mL})\end{array}$ & $\begin{array}{l}\text { Accidental ingestion. Preexisting AFLD, presently reduced alcohol use. Dizziness. } \\
\text { Slightly increased serum activities of AST and ALT. }\end{array}$ \\
\hline $\begin{array}{l}\text { 41. Male, } \\
16 \text { years }\end{array}$ & $\begin{array}{l}\text { Trichloroethylene; } \\
\text { Ingestion }(300 \mathrm{~mL})\end{array}$ & $\begin{array}{l}\text { Intentional ingestion. Narcosis. Marginally increased serum activities of AST and } \\
\text { ALT. }\end{array}$ \\
\hline $\begin{array}{l}\text { 42. Male, } \\
18 \text { years }\end{array}$ & $\begin{array}{l}\text { Trichloroethylene; } \\
\text { Ingestion }(>10 \mathrm{~mL})\end{array}$ & $\begin{array}{l}\text { Unintentional ingestion after drinking } 1.0 \mathrm{~L} \text { beer. Nausea, narcosis. Slightly } \\
\text { increased serum activities of AST and ALT. }\end{array}$ \\
\hline $\begin{array}{l}\text { 43. Male, } \\
67 \text { years }\end{array}$ & $\begin{array}{l}\text { Trichloroethylene; } \\
\text { Ingestion ( } 30 \mathrm{~mL})\end{array}$ & $\begin{array}{l}\text { Accidental ingestion. Following gastrointestinal lavage and under } \mathrm{CO}_{2} \text {-induced } \\
\text { hyperventilation, serum activities of AST and ALT remained normal. }\end{array}$ \\
\hline $\begin{array}{l}\text { 44. Male, } \\
49 \text { years }\end{array}$ & $\begin{array}{l}\text { Trichloroethylene; } \\
\text { Ingestion }(90 \mathrm{~mL})\end{array}$ & $\begin{array}{l}\text { Intentional ingestion together with Stroh rum. Known alcohol abuse. Vomiting, } \\
\text { narcosis, endotracheal intubation, subsequent gastrointestinal lavage. Suspected } \\
\text { shock in lungs, artificial ventilation combined with } \mathrm{CO}_{2} \text {-induced hyperventilation, } \\
\text { whereby } \mathrm{CO}_{2} \text { was added to the inspiration air. Serum activities of AST and ALT } \\
\text { moderately increased at admission, thereafter rapid normalization. }\end{array}$ \\
\hline $\begin{array}{l}\text { 45. Male, } \\
17 \text { years }\end{array}$ & $\begin{array}{l}\text { Trichloroethylene; } \\
\text { Ingestion }(70 \mathrm{~mL})\end{array}$ & $\begin{array}{l}\text { Unintentional ingestion. Somnolence. Vomiting. Normal serum AST and ALT } \\
\text { activities. }\end{array}$ \\
\hline
\end{tabular}


Teschke R.: Aliphatic halogenated hydrocarbons and liver

Table 2. (continued)

\begin{tabular}{|c|c|c|}
\hline Case & $\begin{array}{l}\text { AHH intoxication; } \\
\text { Route (amount) }\end{array}$ & Selected case details of 52 patients under $\mathrm{CO}_{2}$-induced hyperventilation \\
\hline $\begin{array}{l}\text { 46. Male, } \\
26 \text { years }\end{array}$ & $\begin{array}{l}\text { Trichloroethylene; } \\
\text { Ingestion }(100 \mathrm{~mL})\end{array}$ & $\begin{array}{l}\text { Intentional ingestion. Alcohol abuse. Vomiting. Narcosis. Transfer by plane. Serum } \\
\text { activities of AST and ALT remained in normal range. }\end{array}$ \\
\hline $\begin{array}{l}47 . \text { Female, } \\
20 \text { years }\end{array}$ & $\begin{array}{l}\text { Trichloroethylene; } \\
\text { Ingestion }(100 \mathrm{~mL})\end{array}$ & $\begin{array}{l}\text { Intentional ingestion, together with diclofenac }(1.0 \mathrm{~g}) \text {, hydrochlorothiazide }(1.5 \mathrm{~g}) \text {, } \\
\text { and acetyl salicylic acid }(5.6 \mathrm{~g}) \text {. Narcosis, endotracheal intubation. After transfer, } \\
\text { start with hyperventilation by means of a respirator and adding } \mathrm{CO}_{2} \text { to the } \\
\text { inspiration mixture, which reduced serum trichloroethylene levels from }>1 \mathrm{mg} / \mathrm{mL} \\
\text { down to } 1 \mu \mathrm{g} / \mathrm{mL} \text {. Serum activities of AST and ALT remained normal. The clinical } \\
\text { course was fatal due to respiratory insufficiency and complications, ascertained by } \\
\text { autopsy: Purulent trachea-bronchitis, pneumonia, and congestion of the liver. }\end{array}$ \\
\hline $\begin{array}{l}\text { 48. Male, } \\
28 \text { years }\end{array}$ & $\begin{array}{l}\text { Trichloroethylene; } \\
\text { Ingestion (>500 } \mathrm{mL})\end{array}$ & $\begin{array}{l}\text { Intentional ingestion. Spontaneous and later self-induced vomiting. Narcosis. } \\
\text { Serum activities of AST and ALT remained in the normal range. }\end{array}$ \\
\hline $\begin{array}{l}\text { 49. Male, } \\
49 \text { years }\end{array}$ & $\begin{array}{l}\text { Trichloroethylene; } \\
\text { Ingestion ( } 700 \mathrm{~mL})\end{array}$ & $\begin{array}{l}\text { Intentional ingestion. Somnolence. Became wet, fecal leakage. Known alcohol } \\
\text { abuse. Marginally increased serum activities of AST and ALT. }\end{array}$ \\
\hline $\begin{array}{l}50 . \text { Female, } \\
40 \text { years }\end{array}$ & $\begin{array}{l}\text { Trichloroethylene; } \\
\text { Ingestion ( } 200 \mathrm{~mL})\end{array}$ & $\begin{array}{l}\text { Intentional ingestion. Narcosis, fecal leakage. Minimally increased activities of AST } \\
\text { and ALT. }\end{array}$ \\
\hline $\begin{array}{l}\text { 51. Male, } \\
51 \text { years }\end{array}$ & $\begin{array}{l}\text { Tetrachloroethylene; } \\
\text { Ingestion }(160 \mathrm{~mL})\end{array}$ & $\begin{array}{l}\text { Accidental ingestion. Dizziness. Self-induced vomiting. Transfer by helicopter. } \\
\text { Serum activities of AST and ALT remained normal. }\end{array}$ \\
\hline $\begin{array}{l}\text { 52. Male, } \\
61 \text { years }\end{array}$ & $\begin{array}{l}\text { Tetrachloroethylene; } \\
\text { Ingestion }(500 \mathrm{~mL})\end{array}$ & $\begin{array}{l}\text { Intentional ingestion. Narcosis. Complicated clinical course with aspiration } \\
\text { pneumonia. Minimally increased serum activities of AST and ALT. }\end{array}$ \\
\hline
\end{tabular}

Case data are presented in condensed form. For listed patients with intoxications by $\mathrm{CCl}_{4}$, many additional data of interest are available, though not included in this table; the data had been reported previously in a recent publication. ${ }^{16}$ For all patients with intoxication by ingestion of $\mathrm{AHH}$, treatment was commonly initiated in the local hospital by gastrointestinal lavage, sometimes already. Intoxicated patients by ingestion or inhalation all received the $\mathrm{CO}_{2}$-induced hyperventilation therapy, whereby $\mathrm{CO}_{2}$ was provided via nasal tube and rarely via an oxygen mask. A few patients required endotracheal intubation and received $\mathrm{CO}_{2}$ together with the inspiration air. Treatment was provided as outlined (Table 1).

Abbreviations: AFLD, alcoholic fatty liver disease: ALT, alanine transaminase; AST, aspartate transaminase; $\mathrm{CCl}_{4}$, carbon tetrachloride; COPD, chronic obstructive pulmonary disease.

in Table 2), a 19 year-old man, died 122 hours after ingestion of 1,1,2-trichloroethane in unknown amounts and of temazepam after transfer in moribund conditions for hyperventilation therapy at 111 hours following ingestion. The third patient (case 47 in Table 2) was a 20 year-old woman, who had ingested $100 \mathrm{~mL}$ trichloroethylene combined with diclofenac, hydrochlorothiazide, and acetyl salicylic acid. The fourth patient (case 13 in Table 2) was a 36 year-old male, who had ingested $50 \mathrm{~mL} \mathrm{CCl}_{4}, 0.5$ Liter hard liquor, and 1-2 Liter beer, resulting in a blood alcohol level of $3 \&$ at admission.

Various factors may influence the clinical outcome. These include early start and extent of primary toxin elimination through vomiting, gastrointestinal lavage, and $\mathrm{CO}_{2}$-induced hyperventilation, apart from effectivity of the intravenously applied cimetidine and glucose in high amounts. Risk factors are also intentional intoxication, uptake of high amounts of $\mathrm{AHH}$, concomitant ingestion of overdosed drugs with high amounts of alcohol, and a history of alcohol abuse.

\section{Individual cases with liver injury caused by specific AHH}

Dichloromethane: Intoxications caused only small changes in laboratory values (Fig. 2A-2C). The clinical course was without peculiarities (cases $1-3$ in Table 2).

Chloroform: Intoxications occurred in 2 patients (cases 4 and 5 in Table 2), leading to variably increased serum activities of AST and ALT (Fig. 2A and 2B) but leaving serum creatinine levels unchanged (Fig. 2C). As an example, the data for 1 of the cases are presented with all details in Fig. 3A. $\mathbf{C C l}_{4}$ : For some of the 12 patients experiencing intoxications (cases 6-17 in Table 2), high values were found for serum activities of AST (Fig. 2A) and ALT (Fig. 2B). Although treatment included forced diuresis, patients were also at risk for renal injury, as evidenced by increased serum levels of creatinine (Fig. 2C). The data for 1 patient (case 6 in Table 2) with an uneventful outcome are illustrated in Fig. 3B.

1,2-Dichloroethane: For the overall 18 patients (cases 18-35 in Table 2), laboratory values of serum AST, ALT and creatinine were only moderately elevated or remained in the normal range (Fig. $2 \mathrm{~A}-2 \mathrm{C}$ ). The data for a typical case are presented with all details in Fig. 4A.

1,1,2-Trichloroethane: Considered were 2 patients (cases 36 and 37 in Table 2). Only 1 of the patients presented with high laboratory values (Fig. 2A-2C).

Trichloroethylene: For all 13 patients (cases 38-50 in Table 2), laboratory values were mostly unchanged or rarely moderately increased (Fig. 2A-2C). The data for 1 of these patients are given with all details in Fig. 4B.

Tetrachloroethylene: Among the 2 patients (cases 51 and 52 in Table 2), serum activities of aminotransferases were either unchanged or slightly increased (Fig. 2A and 2B), whereas serum creatinine presented with moderately increased levels despite forced diuresis (Fig. 2C).

Mixed AHH chemical intoxications: Overall, 8 patients experienced intoxications with variable combinations of $\mathrm{AHH}$ chemicals (cases 1-8 in Table 3 ). Serum activities remained unchanged or were slightly increased for AST (Fig. 2A) and 
Teschke R.: Aliphatic halogenated hydrocarbons and liver

Table 3. Summary of case details of 8 patients with acute mixed chemical intoxication by aliphatic halogenated hydrocarbons and other chemicals

\begin{tabular}{|c|c|c|c|c|}
\hline Patient & Intoxicating chemicals & Amounts & Route of uptake & Outcome \\
\hline 1. & $\begin{array}{l}\text { Dichloromethane } \\
\text { Methylethylketone } \\
\text { Toluene-2,4-diisocyanate } \\
\text { Ethanol (absolute) }\end{array}$ & $\begin{array}{l}30 \mathrm{~mL} \\
25 \mathrm{~mL} \\
30 \mathrm{~mL} \\
25 \mathrm{~mL}\end{array}$ & All by ingestion & Favorable \\
\hline 2. & $\begin{array}{l}\text { Dichloromethane } \\
\text { Trichloroethane } \\
\text { Tetrachloroethylene } \\
\text { Benzene }\end{array}$ & $\begin{array}{l}25 \mathrm{~mL} \\
25 \mathrm{~mL} \\
50 \mathrm{~mL} \\
25 \mathrm{~mL}\end{array}$ & All by ingestion & Favorable \\
\hline 3. & $\begin{array}{l}\text { Dichloromethane } \\
\text { Toluene }\end{array}$ & $\begin{array}{l}100 \mathrm{~mL} \\
20 \mathrm{~mL}\end{array}$ & All by ingestion & Favorable \\
\hline 4. & $\begin{array}{l}\mathrm{CCl}_{4} \\
\text { Diethylether } \\
\text { Clenbuterol } \\
\text { Oxeladin }\end{array}$ & $\begin{array}{l}\text { Unknown } \\
\text { Unknown } \sim 30 \mathrm{~mL} \\
\text { Unknown }\end{array}$ & All by ingestion & Favorable \\
\hline 5. & $\begin{array}{l}\mathrm{CCl}_{4} \\
\text { Trichloroethylene } \\
\text { Tetrachloroethylene } \\
\text { Diethylether }\end{array}$ & $\begin{array}{l}\text { Unknown for } \\
\text { all chemicals }\end{array}$ & All by inhalation & Favorable \\
\hline 6. & $\begin{array}{l}\mathrm{CCl}_{4} \\
\text { Tetrachloroethylene }\end{array}$ & $\begin{array}{l}\text { Unknown for } \\
\text { all chemicals }\end{array}$ & All by inhalation & Favorable \\
\hline 7. & $\begin{array}{l}\text { 1,2-Dichloroethane } \\
\text { 1,1,2-Trichloroethane }\end{array}$ & $\begin{array}{l}60 \mathrm{~mL} \\
90 \mathrm{~mL}\end{array}$ & All by ingestion & Fatal \\
\hline 8. & $\begin{array}{l}\text { Trichloroethylene } \\
\text { Tetrachloroethylene } \\
\text { Benzene } \\
\text { Toluol } \\
\text { Xylol }\end{array}$ & $\begin{array}{l}\text { Unknown for } \\
\text { all chemicals }\end{array}$ & All by inhalation & Favorable \\
\hline
\end{tabular}

Only patients intoxicated by ingestion received a gastrointestinal lavage, all patients were treated with the $\mathrm{CO}_{2}$-induced hyperventilation according to described details (Table 1 ). Abbreviation: $\mathrm{CCl}_{4}$, carbon tetrachloride.
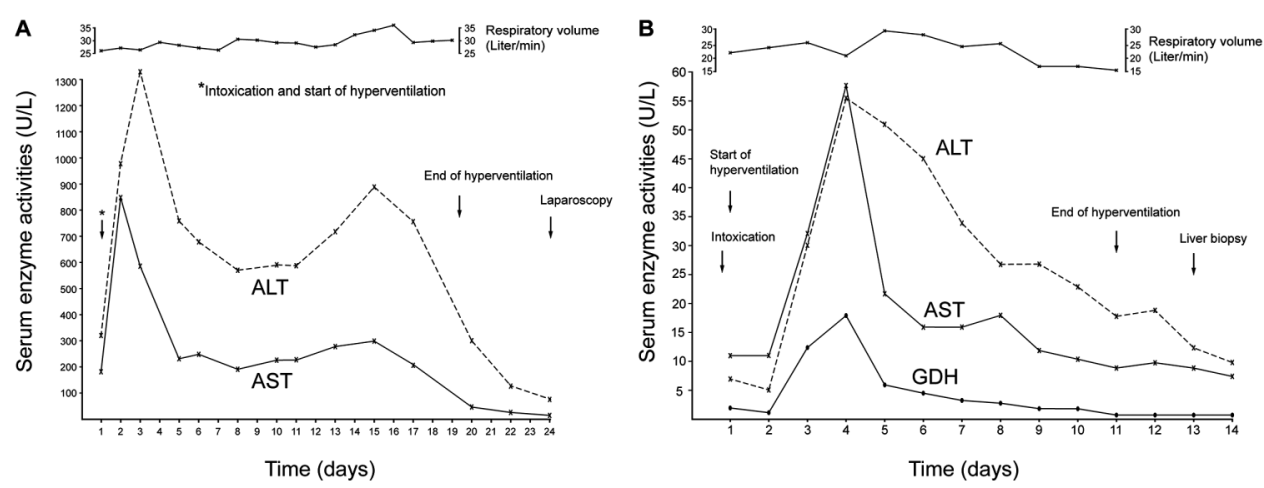

Fig. 3. (A) Serum activities of AST and ALT after intoxication by ingested chloroform. The patient (case 4 in Table 2 ) was a house painter and had stored chloroform in a beer bottle, from which he erroneously ingested $50 \mathrm{~mL}$ chloroform. Prior to intoxication, he had drank $1.5 \mathrm{~L}$ beer contained in other beer bottles. Narcosis requiring endotracheal intubation for gastrointestinal lavage and short-term artificial ventilation. The $\mathrm{CO}_{2}$-induced hyperventilation was started 6 hours after ingestion, whereby a respiratory volume between 24 and 34 Liter min-1 was achieved as shown at the top of the figure. Via a nasal tube, $\mathrm{CO}_{2}$ was provided at a flow rate of 3 to 6 Liter min ${ }^{-1}$. Blood showed pH that was between 7.36 and $7.46, \mathrm{PO}_{2}$ between 83 and $110 \mathrm{mmHg}, \mathrm{PCO}_{2}$ between 35 and 55 , and $\mathrm{HCO}_{3}$ between 21 and 31 , and respiratory frequency between 15 and 30 min ${ }^{-1}$. The therapy using hyperventilation was well tolerated by the cooperative patient and had to be extended for 19 days because serum activities of AST and ALT declined slowly. Serum activities of liver enzymes showed two peaks. On day 2 , AST was $850 \mathrm{U} / \mathrm{L}$ and ALT was $1330 \mathrm{U} / \mathrm{L}$ on day 3 . Both enzymes declined and had a second peak on day 15 , with AST of $300 \mathrm{U} / \mathrm{L}$ and ALT of $890 \mathrm{U} / \mathrm{L}$. Total bilirubin was in a range between 0.8 and $2.1 \mathrm{mg} / \mathrm{dL}$. Hemoglobin was between 11.8 and 15.5 , erythrocytes between 3800 and 4800 , leucocytes between 5.100 and 11500 . Serum creatinine remained in the normal range, considering that forced diuresis was provided for prophylactic reasons. Liver biopsy obtained at laparoscopy on day 24 revealed a striking proliferation of stellate cells, no fatty changes of the hepatocytes, and no necrosis by light microscopy. (B) Serum activities of AST, ALT, and GDH after intoxication by ingested $\mathbf{C C l}_{\mathbf{4}}$. The patient (case 6 in Table 2) intentionally swallowed $30 \mathrm{~mL} \mathrm{CCl}_{4}$, vomited twice, and received a gastrointestinal lavage. $\mathrm{CO}_{2}$-induced hyperventilation was started 9 hours after intoxication and continued for 11 days. $\mathrm{CO}_{2}$ was applied via a nasal tube at a flow rate of $2-4 \mathrm{Liter}$ min ${ }^{-1}$ and resulted in a

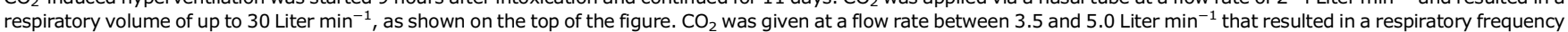
ranging from 28 to 36 per minute. Blood showed pH of 7.31 to $7.33, \mathrm{PO}_{2}$ of around $111, \mathrm{HCO}_{3}$ of around 21.3 , and $\mathrm{PCO}$, of around 43.9 . On day 3 after intoxication, serum activities of liver enzymes increased and reached a maximum on day 4 (AST of $59 \mathrm{U} / \mathrm{L}$, ALT of $56 \mathrm{U} / \mathrm{L}$, GDH of $18 \mathrm{U} / \mathrm{L}$ ) and normalized during the next days until day 14 after intoxication. Other laboratory test were in the normal range, except leucocytes (at 14400). Liver biopsy on day 13 showed no abnormalities. The patient was discharged on day 15. Abbreviations: ALT, alanine transaminase; AST, aspartate transaminase; $\mathrm{CCl}_{4}$, carbon tetrachloride; GDH, glutamate dehydrogenase. 
Teschke R.: Aliphatic halogenated hydrocarbons and liver
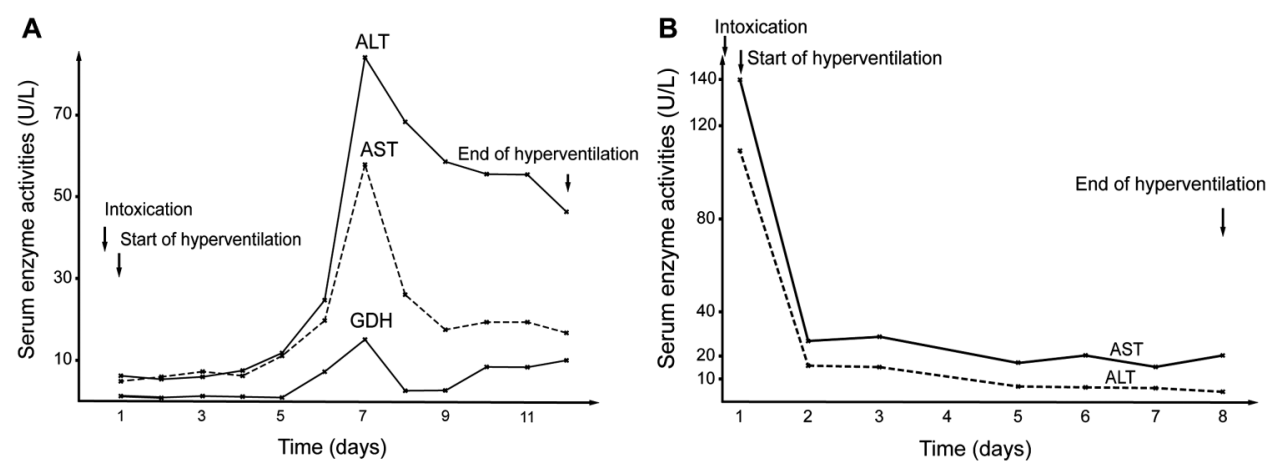

Fig. 4. (A) Serum activities of ALT, AST, and GDH after intoxication by ingested 1,2-dichloroethane. The patient (case 30 in Table 2 ) intentionally ingested $80 \mathrm{~mL}$ dichloroethane. After vomiting and gastrointestinal lavage 4 hours after ingestion, the usual $\mathrm{CO}_{2}$-induced hyperventilation was started using for $\mathrm{CO}_{2}$ application by the nasal tube approach to achieve a respiratory volume between 20 and 33 Liter $\min ^{-1}$ and a respiratory frequency between 20 and 31 per minute. Treatment was for 12 days, prolonged due to slow decline of the liver values. At day 7 after intoxication, maximum serum activities were as follows: AST of $58 \mathrm{U} / \mathrm{L} ; \mathrm{ALT}$ of $85 \mathrm{U} / \mathrm{L}$; and, GDH of $15 \mathrm{U} / \mathrm{L}$. (B) Serum activities of ALT and AST in a patient with ingested trichloroethylene. Presented are data beginning at time of intoxication and during the subsequent clinical course. The patient (case 44 in Table 2) intentionally ingested $70 \mathrm{~mL}$ trichloroethylene together with Stroh rum. Known alcohol abuse. Vomiting, narcosis, endotracheal intubation prior to gastrointestinal lavage. Suspected shock in lungs, artificial ventilation combined with $\mathrm{CO}_{2}$-induced hyperventilation for 8 days, whereby $\mathrm{CO}_{2}$ was added to the inspiration air. Already at admission, the serum activities of AST (140 U/L) and of ALT (110 U/L) were slightly increased, followed by rapid normalization. At laparoscopy 1 month after intoxication, suspicion of fatty liver, confirmed by histology showing severe macrovesicular fatty liver without necrosis or infiltration considered compatible with alcoholic fatty liver but not with alcoholic steatohepatitis or alcoholic hepatitis. Shortly after admission, the patient experienced withdrawal symptoms requiring specific drug treatment. The initially increased AST and ALT activities were likely due to the preexisting alcohol abuse associated with alcoholic fatty liver, considering that AST values were higher than ALT values, providing a ratio of AST/ ALT of $>1.0$ that is highly suggestive for alcohol as cause. Such a ratio was not observed in any other patients intoxicated by AHH, who all had higher values of ALT than of AST.

Abbreviations: ALT, alanine transaminase; AST, aspartate transaminase; GDH, glutamate dehydrogenase.

ALT (Fig. 2B), while serum levels of creatinine were virtually normal except for in 1 patient (Fig. 2C).

\section{Discussion}

This report provides highlights and a comprehensive overview of an innovative therapy approach applied in 60 patients with acute intoxications by $\mathrm{AHH}$, focusing on the $\mathrm{CO}_{2}$-induced hyperventilation (Table 1 ). The basic idea to treat patients intoxicated by $\mathrm{AHH}$ using forced ventilation originated from preliminary results of a single case published by PebayPeyroula and Nicaise. ${ }^{23}$ Subsequently, this new form of therapy was clinically introduced and refined at the Heinrich Heine University hospital of Düsseldorf in Germany, first in children ${ }^{18,24}$ and later in adults, with the aim to present practical and specific recommendations (Table 1). ${ }^{15,16}$

Several experimental and clinical studies have since provided additional data in support of the $\mathrm{CO}_{2}$-induced hyperventilation therapy. For instance, intoxicating $\mathrm{AHH}$, such as $\mathrm{CCl}_{4}$, taken up by animals are mostly eliminated (99\%) through the lungs, ${ }^{25}$ while up to $44 \%$ of the $\mathrm{AHH}$ taken up by humans are eliminated via the lungs at a rate of up to $44 \%$ within the first hour. ${ }^{26}$ Furthermore, addition of $\mathrm{CO}_{2}$ to the inspiration air of patients with $\mathrm{AHH}$ intoxication increased the minute respiration volume via an increased respiration frequency, and pulmonary exhalation of $\mathrm{CCl}_{4}$ was in parallel with the minute respiratory expiration volume. ${ }^{16}$ Reduced respiration due to pneumonia caused increased blood levels of $\mathrm{CCl}_{4}$ in intoxicated patients. ${ }^{14,16}$ Conditions similar to intermittent interruption of the hyperventilation therapy that also led to temporarily increased blood levels of $\mathrm{CCl}_{4}$ until reintroduction of the $\mathrm{CO}_{2}$-induced hyperventilation therapy again caused a decline of blood levels. ${ }^{16}$ The beneficial effect of hyperventilation had been ascertained in an experimental model of liver injury by $\mathrm{CCl}_{4} \cdot{ }^{11,12,14}$ For instance, experimental $\mathrm{CO}_{2}$-induced hyperventilation applied in $\mathrm{CCl}_{4}$ intoxication attenuated the extent of liver injury, ${ }^{11}$ significantly reduced the $\mathrm{LD}_{50},{ }^{11,16,27}$ and diminished $\mathrm{CCl}_{4}$ levels in blood, liver and fat tissue. ${ }^{12,16}$ The combination of these facts led to the refinement of the hyperventilation therapy ${ }^{15,16}$ that was applied in the 60 patients of this study (Supplemental Tables 1 and 2).

In the clinical setting of the studied 60 patients with $\mathrm{AHH}$ intoxication, the individual contribution of hyperventilation on reducing liver injury is difficult to assess, due to existing confounders. For instance, the study cohort was not homogenous with respect to variability of $\mathrm{AHH}$ as intoxication chemicals; most patients experienced vomiting which contributed to toxin elimination, and all patients with intoxication by ingestion received a gastrointestinal lavage for primary toxin elimination. Finally, patients intoxicated by ingestion or inhalation received a therapy that included high glucose infusion and intravenously given cimetidine. Considering the liver test results for AST and ALT, in a few patients the serum activities of AST and ALT remained in the normal range during the observation period under therapy. Other patients had high serum activities of AST (Fig. 2A) and ALT (Fig. 2B), suggesting that the therapy approaches taken together will not be able to prevent liver injury completely. Nevertheless, clinical experience strongly suggests that therapy for intoxicated patients should be initiated as soon as possible, starting with gastrointestinal lavage in the intubated patient with intoxication by ingestion as the first measure in the local hospital that first takes care of the patient.

Intoxications by $\mathrm{AHH}$ and related liver toxicity is a worldwide issue, with partially high lethality rates as shown by abundant publications; as examples, a few of these are selectively referenced. ${ }^{28-49}$ The low lethality rate of $6.7 \%$ in the present study is encouraging but cannot be fully appreciated due to the lack of an appropriate control group of patients who did not receive the therapy outlined in this study (Table 1 ). Despite these shortcomings, it is hoped that more patients with acute $\mathrm{AHH}$ intoxications will receive this therapy and experience their 
benefits rather than being confronted with a risky wait-and-see approach by their physicians.

\section{Conclusions}

With the establishment of modern, active therapeutic approaches, including $\mathrm{CO}_{2}$-induced hyperventilation, the prognosis is now substantially better for patients acutely intoxicated by $\mathrm{AHH}$, provided treatment is initiated without delay and replacing a wait-and-see approach conflicted by poor prognosis. In the near future, progress can be expected after successful search for additional drugs or compounds that provide inhibition of $\mathrm{AHH}$ metabolism, which may be better than the cimetidine that is used as the preferred drug presently. Studying such inhibition at the level of CYP 2E1 is facilitated using experimental $\mathrm{CCl}_{4}$ models, because their result can easily be transferred to patients intoxicated by $\mathrm{CCl}_{4}$ or other $\mathrm{AHH}$. Inhibitor candidates may come from drugs already on the market or from Herbal \& Traditional Chinese Medicine.

\section{Acknowledgement}

The author is in debt to previous members of the working group at the Heinrich Heine University in Düsseldorf (Germany): H. Frenzel, J. Gellert, L. Goldermann, K.H. Hauptmeier, T. Heidenreich and W. Vierke, who were authors of own published work or co-authors of publications all referenced in this article.

\section{Conflict of interest}

The author has no conflict of interests related to this publication.

\section{Author contributions}

Conception and design of the study, data collection and analysis, and writing of the manuscript (RT).

\section{References}

[1] Zimmerman HJ. Hepatotoxicity. Philadelphia: Lippincott Williams \& Wilkins, 1999.

[2] Helmenstine AM. Aliphatic hydrocarbon definition. Available from: https://www.thoughtco.com/definition-of-aliphatic-hydrocarbon-604763.

[3] Raucy JL, Kraner JC, Lasker JM. Bioactivation of halogenated hydrocarbons by cytochrome P4502E1. Crit Rev Toxicol 1993;23:1-20. doi: 10.3109/ 10408449309104072.

[4] Plaa GL. Chlorinated methanes and liver injury: highlights of the past 50 years. Annu Rev Pharmacol Toxicol 2000;40:42-65. doi: 10.1146/annurev. pharmtox.40.1.43.

[5] Recknagel RO, Glende EA Jr, Dolak JA, Waller RL. Mechanisms of carbon tetrachloride toxicity. Pharmacol Ther 1989;43:139-154. doi: 10.1016/ 0163-7258(89)90050-8.

[6] Weber LW, Boll M, Stampfl A. Hepatotoxicity and mechanism of action of haloalkanes: carbon tetrachloride as a toxicological model. Crit Rev Toxicol 2003;33:105-136. doi: 10.1080/713611034.

[7] Hasumura $Y$, Teschke R, Lieber CS. Increased carbon tetrachloride hepatotoxicity, and its mechanism, after chronic ethanol consumption. Gastroenterology 1974;66:415-422. doi: 10.1016/S0016-5085(74)80142-3.

[8] Teschke R, Vierke W, Goldermann L. Carbon tetrachloride ( $\mathrm{CCl} 4)$ levels and serum activities of liver enzymes following acute $\mathrm{CCl} 4$ intoxication. Toxicol Lett 1983;17:175-180. doi: 10.1016/0378-4274(83)90054-1.

[9] Vierke W, Gellert J, Teschke R. Head-space gas chromatographic analysis for rapid quantitative determination of carbon tetrachloride in blood and liver of rats. Arch Toxicol 1982;51:91-99. doi: 10.1007/bf00279324.
[10] Teschke $\mathrm{R}$, Hauptmeier $\mathrm{KH}$, Frenzel $\mathrm{H}$. Effect of an acute dose of ethanol on the hepatotoxicity due to carbon tetrachloride. Liver 1983;3:100-109. doi: 10.1111/j.1600-0676.1983.tb00856.x.

[11] Frenzel $\mathrm{H}$, Heidenreich T, Gellert J, Teschke R. Protective effect of $\mathrm{CO}_{2}$-induced hyperventilation on the hepatotoxicity elicited by carbon tetrachloride. Liver 1982;2:376-384. doi: 10.1111/j.1600-0676.1982.tb00837.x.

[12] Gellert J, Goldermann L, Teschke R. Effect of $\mathrm{CO}_{2}$-induced hyperventilation on carbon tetrachloride $(\mathrm{CCl} 4)$ levels following acute $\mathrm{CCl} 4$ poisoning. Intensive Care Med 1983;9:333-337. doi: 10.1007/bf01692552.

[13] Homann J, Rotter S, Schneider S, Röttger P, Kratz F, Kroker R, et al. Influence of cimetidine on $\mathrm{ccl} 4$-induced liver injury and survival in rats. Biochem Pharmacol 1985;34:415-416. doi: 10.1016/0006-2952(85)90066-8.

[14] Goldermann L, Gellert J, Teschke R. Quantitative assessment of carbon tetrachloride levels in human blood by head-space gas chromatography: application in a case of suicidal carbon tetrachloride intoxication. Intensive Care Med 1983:9:131-135. doi: 10.1007/bf01772580.

[15] Teschke R. Review: Intoxications by aliphatic halogenated hydrocarbons: hepatotoxic risks for patients and clinical issues including role of $\mathrm{CO}_{2}$-induced hyperventilation as therapy option. J Clin Exp Tox 2018;2: 20-24.

[16] Teschke R. Liver injury by carbon tetrachloride intoxication in 16 patients treated with forced ventilation to accelerate toxin removal via the lungs: A clinical report. Toxics 2018;6:25. doi: 10.3390/toxics6020025.

[17] Teschke R. Alcoholic steatohepatitis (ASH) and alcoholic hepatitis (AH): cascade of events, clinical aspects, and pharmacotherapy options. Expert Opin Pharmacother 2018;19:779-793. doi: 10.1080/14656566.2018. 1465929.

[18] Pothmann R, Lemburg P, Sprock I, Göbel U. Hyperventilationstherapie bei oraler Vergiftung mit halogenierten Kohlenwasserstoffen. In: Lemburg P, ed. Pädiatrische Intensivemedizin II. Thieme Stuttgart, 1981:229-233.

[19] Pischik E, Kauppinen R. An update of clinical management of acute intermittent porphyria. Appl Clin Genet 2015;8:201-214. doi: 10.2147/TACG. S48605.

[20] Tschudy DP, Welland FH, Collins A, Hunter G Jr. The effect of carbohydrate feeding on the induction of delta-aminolevulinic acid synthetase. Metabolism 1964;13:396-406. doi: 10.1016/0026-0495(64)90113-1.

[21] Puy H, Deybach JC. Haem biosynthesis and excretion of porphyrins. Chapter 2.3.10. In: Rodés J, Benhamou JP, Blei A, Reichen J, Rizzetto M, ed. Textbook of Hepatology, third edition. eBooks, GastroHep.com, 2018:207-214. Available from: http://www.gastrohep.com/ebooks/rodes/Rodes_2_3_10. pdf. Accessed July 282018.

[22] Levin $W$, Jacobson $M$, Kutzman $R$. Incorporation of radioactive-deltaaminolevulinic acid into microsomal cytochrome $P_{450}$. Arch Biochem Biophys 1972;148:262-269. doi: 10.1016/0003-9861(72)90140-3.

[23] Pebay-Peyroula F. Pulmonary elimination of poisons. Measurement. Toxicological applications. Eur J Toxicol 1970;3:300-308.

[24] Lemburg P, Sprock I, Bretschneider A, Storm W, Göbel U. A new concept of therapy in accidental intoxications with halogenated hydrocarbons. Vet Hum Toxicol 1979;21 Suppl:37-40.

[25] McLean AEM. Drugs, diet and liver injury. In: Gerok W, Sickinger K, ed. Drugs and the Liver. Schattauer Stuttgart, 1975:143-148.

[26] Morgan A, Black A, Belcher DR. The excretion in breath of some aliphatic halogenated hydrocarbons following administration by inhalation. Ann Occup Hyg 1970;13:219-233. doi: 10.1093/annhyg/13.4.219.

[27] Gellert J, Frenzel H, Heidenreich T, Goldermann L, Vierke W, Teschke R. Effektivität der $\mathrm{CO}_{2}$-induzierten Hyperventilationstherapie durch halogenierte Kohlenwasserstoffe. Intensivmed 1982;19:293-297.

[28] Schlosser PM, Bale AS, Gibbons CF, Wilkins A, Cooper GS. Human health effects of dichloromethane: key findings and scientific issues. Environ Health Perspect 2015;123:114-119. doi: 10.1289/ehp.1308030.

[29] U.S. Environmental Protection Agency (EPA). Toxicological review of dichloromethane (methylene chloride). Available from: https://cfpub.epa. gov/ncea/iris/iris_documents/documents/toxreviews/0070tr.pdf. Accessed November 2011.

[30] Kim NY, Park SW, Suh JK. Two fatal cases of dichloromethane or chloroform poisoning. J Forensic Sci 1996;41:527-529. doi: 10.1520/jfs13951j.

[31] TOXNET. Dichloromethane. Available from: https://toxnet.nlm.nih.gov/cgibin/sis/search/a?dbs+hsdb:@term+@DOCNO+66.

[32] Bomski H, Sobolewska A, Strakowski A. Toxic damage of the liver by chloroform in chemical industry workers. Int Arch Arbeitsmed 1967;24: 127-134.

[33] Lee DG, Lee CH, Jang KH, Chae HJ, Moon JD. A suspicious case of chloroform induced acute toxic hepatitis in laboratory worker. Korean J Occup Environ Med 2012;24:304-310.

[34] Docherty JF, Burgess E. The action of carbon tetrachloride on the liver. Br Med J 1922;2:907-908. doi: 10.1136/bmj.2.3228.907.

[35] McGuire LW. Carbon tetrachloride poisoning. JAMA 1932;99:988-989. doi: 10.1001/jama.1932.02740640030008.

[36] Lehnherr ER. Acute carbon tetrachloride poisoning: Report of a case. Arch Int Med 1935;56:98-104. doi: 10.1001/archinte.1935.03920010106007. 
[37] Moon HD. The pathology of fatal carbon tetrachloride poisoning with special reference to the histogenesis of the hepatic and renal lesions. Am J Pathol 1950;26:1041-1057.

[38] Jennings RB. Fatal fulminant acute carbon tetrachloride poisoning. AMA Arch Pathol 1955;59:269-284.

[39] Guild WR, Young JV, Merrill JP. Anuria due to carbon tetrachloride intoxication. Ann Intern Med 1958;48:1221-1227. doi: 10.7326/0003-4819-48-61221.

[40] Truss CD, Killenberg PG. Treatment of carbon tetrachloride poisoning with hyperbaric oxygen. Gastroenterology 1982;82:767-769.

[41] Ruprah M, Mant TG, Flanagan RJ. Acute carbon tetrachloride poisoning in 19 patients: implications for diagnosis and treatment. Lancet 1985;1: 1027-1029. doi: 10.1016/S0140-6736(85)91624-1.

[42] Mydlík M, Derzsiová K, Frank K. Renal replacement therapy in acute poisonings-one center experience. Przegl Lek 2013;70:381-385.

[43] Martin G, Knorpp K, Huth K, Heinrich F, Mittermayer C. Zur Klinik, Pathogenese und Therapie der Dichloräthan-vergiftung. Dtsch Med Wschr 1968;93: 2002-2010. doi: 10.1055/s-0028-1110869.
[44] 1,1,2-Trichloroethane. Available from: https://pubchem.ncbi.nlm.nih.gov/ compound/6574.

[45] Agency for Toxic Substances and Disease Registry. U.S. Public Health Service. Toxicological profile for 1,1,2-Trichloroethane. Available from: https://www. atsdr.cdc.gov/toxprofiles/tp148.pdf. Accessed December 1989.

[46] TOXNET. Toxicology Data Network. U.S. National Library of Medicine. Trichloroethylene. Available from: https://toxnet.nlm.nih.gov/cgi-bin/sis/search2/f?. /temp/ xveGMT: 1 .

[47] U.S. Department of Health and Human Services, Public Health Services. Agency for Toxic Substances and Disease Registry (ATSDR). Draft toxicological profile for tetrachloroethylene. Available from: https://www.atsdr.cdc. gov/toxprofiles/tp18.pdf. Accessed October 2014.

[48] Gold LS, De Roos AJ, Waters M, Stewart P. Systematic literature review of uses and levels of occupational exposure to tetrachloroethylene. J Occup Environ Hyg 2008;5:807-839. doi: 10.1080/15459620802510866.

[49] Shen C, Zhao CY, Liu F, Wang YD, Wang W. Acute liver failure associated with occupational exposure to tetrachloroethylene. J Korean Med Sci 2011;26: 138-142. doi: 10.3346/jkms.2011.26.1.138. 